\title{
GAMBARAN HISTOPATOLOGI LAMBUNG TIKUS WISTAR YANG DIBERI CABE RAWIT (Capsicum frutescens)
}

\author{
${ }^{1}$ Philip Teng \\ ${ }^{2}$ Carla Kairupan \\ ${ }^{2}$ Lily Loho \\ ${ }^{1}$ Kandidat Skripsi Fakultas Kedokteran Universitas Sam Ratulangi \\ ${ }^{2}$ Bagian Patologi Anatomi Fakultas Kedokteran Universitas Sam Ratulangi Manado \\ Email: takatophilip@yahoo.com
}

\begin{abstract}
Capsaicin is one of the active substantial that can be found in chili pepper and one of the irritant for mammal that causing the burning sensation. The discomfort sensation in the gastric by capsaicin can be caused because the Transient receptor potential vanilloid-1 that can be found in gastric is stimulated. Objective: To demonstrate the gastric that was administered with chili pepper. Method: The study conducted on Integrated Research Laboratory Faculty of Medicine Sam Ratulangi University Manado from October 2012 to January 2013. The study used 17 wistars, which divided to 5 groups and last to 7 days. This study was using chili pepper in 45mg, 90mg, 135mg, and 180mg to study the histological changes of wistar rat's gastric. Results: The result showed that the administration of 180mg dose of chili pepper did not cause a meaningful damage. The administration in $90 \mathrm{mg}$ of chili pepper did cause a great damage with many inflammation signs occurring. Conclusions: The administration of chili pepper in little to moderate dose causing a greater damage than the administration of chili pepper in high dose.
\end{abstract}

Keywords: Chili pepper, acute gastritis.

\begin{abstract}
Abstrak: Capsaisin adalah zat aktif yang terkandung dalam cabe rawit dan juga merupakan salah satu bahan iritan bagi mamalia yang dapat menimbulkan sensasi seperti terbakar. Rasa tidak enak di daerah lambung yang diakibatkan oleh capsaicin terjadi oleh adanya stimulasi pada reseptor Transient receptor potential vanilloid-1 yang terdapat pada lambung. Tujuan: Untuk mengetahui bagaimana gambaran histopatologi lambung tikus wistar setelah diberikan cabe rawit. Metode: Penelitian ini dilakukan di Laboratorium Riset Terpadu Fakultas Kedokteran Universitas Sam Ratulangi Manado sejak Oktober 2012 hingga Januari 2013. Penelitian menggunakan 17 ekor tikus wistar yang terdiri dari 5 kelompok perlakuan dan berlangsung selama 7 hari. Penelitian ini menggunakan cabe rawit dalam dosis 45mg, 90mg, 135mg, dan 180mg untuk melihat perubahan gambaran histopatologi lambung tikus wistar. Hasil: Hasil penelitian menunjukkan bahwa penggunaan cabe rawit pada dosis 180mg tidak memperlihatkan kerusakan yang berarti. Penggunaan cabe rawit pada dosis 90mg memperlihatkan kerusakan yang hebat dengan banyak terlihatnya tanda-tanda gastritis akut. Simpulan: Penggunaan cabe rawit dalam jumlah yang sedikit hingga sedang dapat mengakibatkan kerusakan yang lebih dibandingkan dengan penggunaan dalam jumlah yang banyak.
\end{abstract}

Kata Kunci: Cabe rawit, gastritis akut.

Lambung adalah sebuah organ yang berfungsi untuk menyimpan dan mencampur makanan sebelum diteruskan ke duodenum. ${ }^{1}$ Oleh karena itu, lambung selalu terpapar oleh berbagai macam faktor yang dapat merusak jaringan lambung, salah satunya adalah capsaicin. Capsaicin merupakan salah satu bahan iritan bagi mamalia dan dapat menimbulkan sensasi terbakar pada jaringan yang terkena. ${ }^{2}$

Rasa tidak enak yang terjadi di daerah lambung diakibatkan oleh adanya stimulasi pada reseptor Transient receptor potential vanilloid-1 (TRPV1) yang terdapat pada 
pembuluh darah dari dinding lambung. ${ }^{3}$

Berbeda dengan teori sebelumnya, pada beberapa penelitian disebutkan bahwa capsaicin yang dikonsumsi 3 kali sehari sebelum makan, dapat mengurangi gejala dari gangguan pada lambung. Sehingga Capsaicin berpotensi menjadi terapi dispepsia yang baru. ${ }^{4,5}$

Berdasarkan kontroversi tersebut, penulis terdorong untuk meneliti gambaran morfologi lambung tikus wistar setelah diberikan cabe rawit dalam kurun waktu dan dosis tertentu.

\section{METODE PENELITIAN}

Penelitian ini merupakan penelitian eksperimental laboratorik, dilakukan pada periode Oktober 2012-Januari 2013 di Laboratorium Patologi Anatomi Fakultas Kedokteran Universitas Sam Ratulangi Manado. Penelitian ini menggunakan 17 ekor tikus wistar dewasa, yang terdiri dari kelompok kontrol (A) dan kelompok perlakuan yang diberikan diet pelet standar selama 6 hari. Kelompok perlakuan dibagi dalam empat kelompok yaitu kelompok B yang diberikan cabe rawit dengan dosis 45mg/hari, kelompok C yang diberikan cabe rawit dengan dosis 90mg/hari, kelompok D yang diberikan cabe rawit dengan dosis $135 \mathrm{mg} /$ hari, dan kelompok E yang diberikan cae rawit dengan dosis 180mg/hari. Kelima kelompok ini akan diterminasi bersamaan pada hari ke-7. Cabe rawit yang digunakan adalah cae rawit segar yang dapat ditemukan di pasar. Cabe rawit yang telah dijadikan jus diberikan pada hewan uji secara oral (nasogastric tube).

Di akhir penelitian ini, hewan uji diterminasi untuk diambil lambungnya. Lambung tikus diamati secara makroskopik dan mikroskopik kemudian hasilnya disajikan dalam bentuk tabel dan gambar.

\section{HASIL PENELITIAN}

\section{Tikus Wistar kelompok kontrol (A)}

Tikus wistar kelompok ini merupakan kontrol negatif yang hanya diberikan pelet standar selama 6 hari. Pada tikus wistar kelompok ini diperoleh gambaran histologik lambung yang normal. Lapisan mukosa, submukosa, muskularis, dan serosa dalam keadaan normal tanpa adanya sel-sel radang dan edema mukosa.

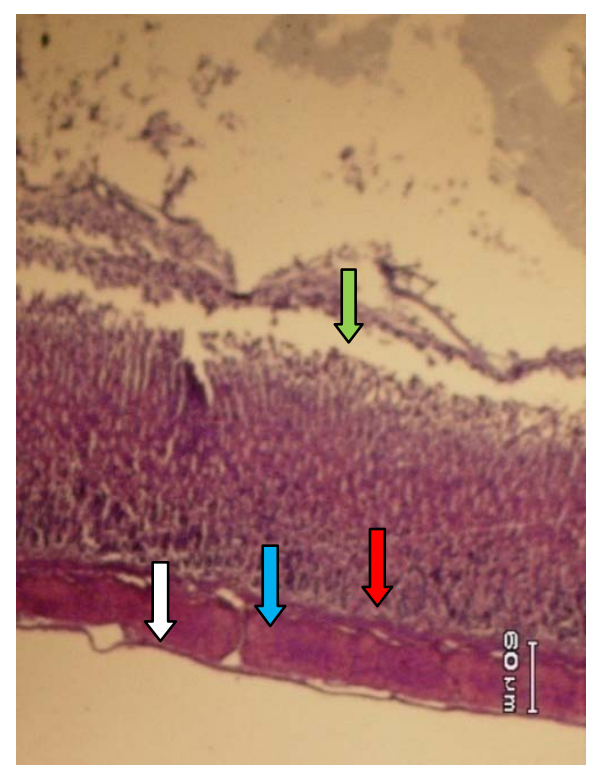

Gambar 1. Gambaran mikroskopik lambung tikus wistar kelompok A, pembesaran 4x10 (panah hijau: lapisan mukosa; panah merah: lapisan submukosa; panah biru: lapisan muskularis; panah putih: lapisan serosa).

\section{Tikus Wistar kelompok B}

Tikus wistar kelompok ini merupakan kelompok yang diberikan cabe rawit dengan dosis $45 \mathrm{mg} /$ hari. Pada kelompok ini terlihat adanya sel-sel radang polymorphonuclear (PMN) pada lapisan mukosa, submukosa, dan muskularis. Tampak pula edema mukosa, perdarahan, dan pelebaran pembuluh darah. 


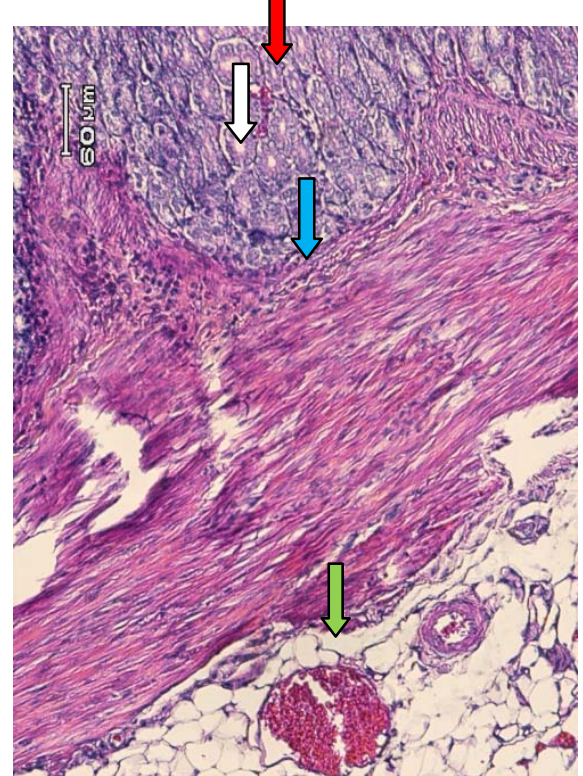

Gambar 2. Gambaran mikroskopik lambung tikus wistar kelompok B, pembesaran 10x. (panah hijau: pelebaran pembuluh darah; panah merah: perdarahan; panah biru: PMN; panah putih: edema mukosa).

\section{Tikus Wistar kelompok C}

Tikus wistar kelompok ini merupakan kelompok yang diberikan cabe rawit dengan dosis 90mg/hari. Pada kelompok ini terlihat adanya sel-sel radang polymorphonuclear (PMN) pada lapisan mukosa, submukosa, dan muskularis. Tampak pula edema mukosa, perdarahan, dan pelebaran pembuluh darah.

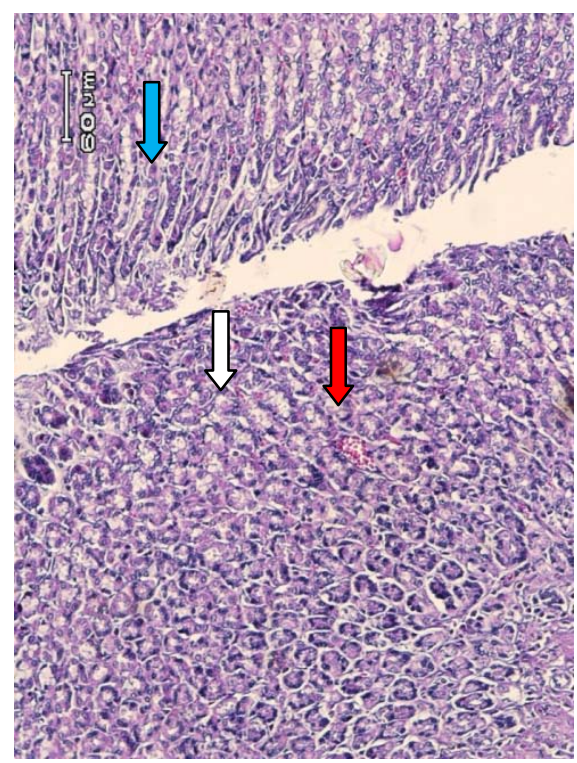

Gambar 3. Gambaran mikroskopik lambung tikus wistar kelompok C, pembesaran 20x.

(panah merah: perdarahan; panah biru: PMN; panah putih: edema mukosa).

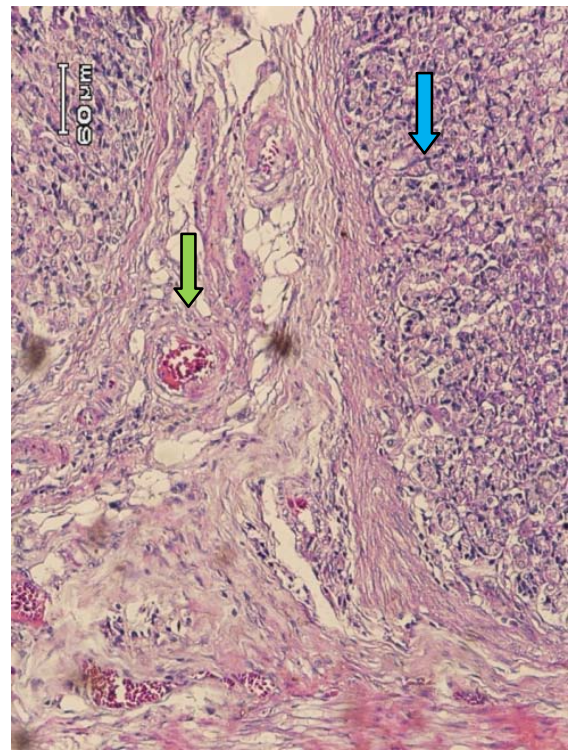

Gambar 4. Gambaran mikroskopik lambung tikus wistar kelompok C, pembesaran 10x. (panah hijau: pelebaran pembuluh darah; panah biru: PMN).

\section{Tikus Wistar kelompok D}

Tikus wistar kelompok ini merupakan kelompok yang diberikan cabe rawit dengan dosis 135mg/hari. Pada kelompok ini terlihat adanya sel-sel radang polymorphonuclear (PMN) pada lapisan mukosa, submukosa, dan muskularis. Tampak pula edema mukosa dan pelebaran pembuluh darah.

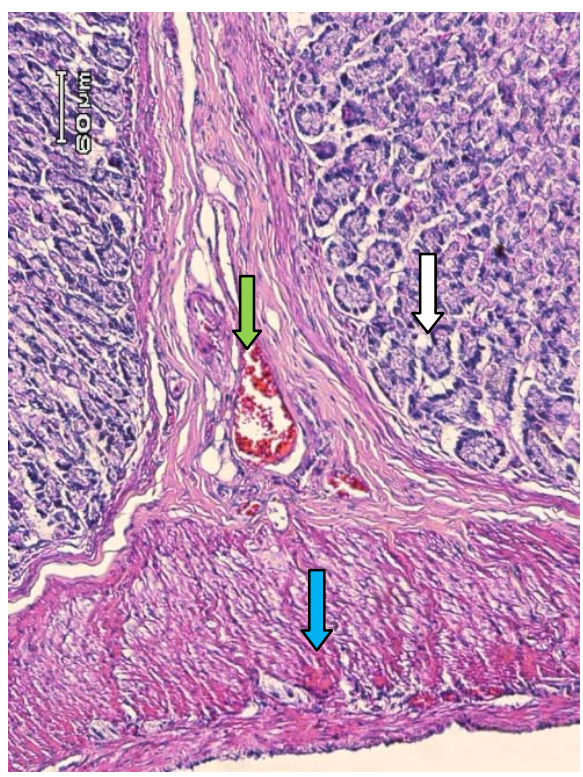

Gambar 5. Gambaran mikroskopik lambung tikus wistar kelompok D, pembesaran 10x. (panah hijau: pelebaran pembuluh darah; panah biru: PMN; panah putih: edema mukosa). 


\section{Tikus Wistar kelompok E}

Tikus wistar kelompok ini merupakan kelompok yang diberikan cabe rawit dengan dosis 180mg/hari. Pada kelompok ini terlihat adanya sel-sel radang polymorphonuclear (PMN) dalam jumlah yang lebih sedikit pada lapisan mukosa, submukosa, dan muskularis. Tampak pula edema mukosa, perdarahan, dan pelebaran pembuluh darah.

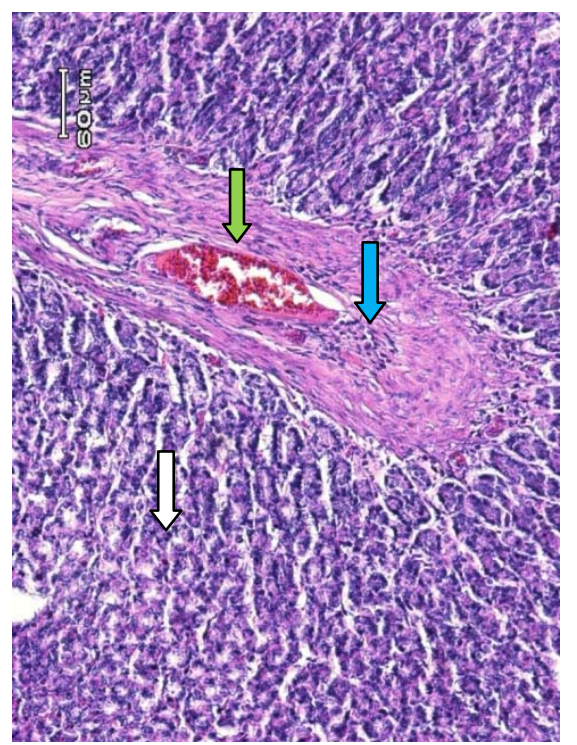

Gambar 6. Gambaran mikroskopik lambung tikus wistar kelompok E, pembesaran 20x. (panah hijau: pelebaran pembuluh darah; panah biru: PMN; panah putih: edema mukosa).

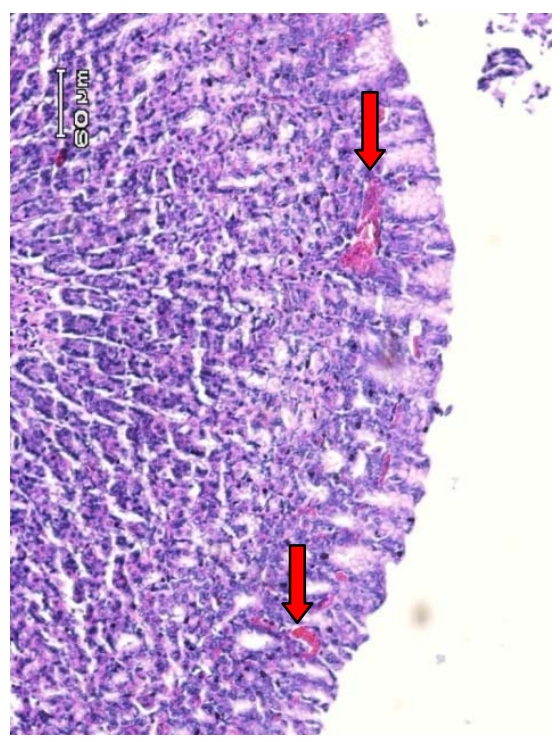

Gambar 7. Gambaran mikroskopik lambung tikus wistar kelompok E, pembesaran 20x. (panah merah: perdarahan).

\section{BAHASAN}

Cabe rawit dapat menyebabkan peradangan pada lambung karena capsaicin yang merupakan komponen utama cabe rawit bersifat iritan terhadap jaringan. ${ }^{2}$

Capsaicin dapat menyebabkan rasa panas dan iritasi pada lambung serta meningkatkan produksi asam lambung dikarenakanan capsaicin memiliki reseptor khusus yang disebut TRPV-1.,3,6

Hasil penelitian ini menunjukkan bahwa lambung tikus wistar kelompok kontrol negative menunjukkan gambaran mikroskopis yang sesuai dengan lambung normal. Demikian pula gambaran mikroskopis lambung tikus wistar yang diberikan cabe rawit sebanyak 45mg dan 90mg memperlihatkan adanya tanda-tanda peradangan akut berupa sel-sel PMN, edema mukosa, pelebaran pembuluh darah dan perdarahan mukosa.

Dibandingkan dengan kelompok tikus wistar yang diberi cabe rawit sebanyak 45mg, 90mg, dan 135mg, kelompok tikus wistar yang diberikan cabe rawit sebanyak 180mg memiliki gambaran mikroskopik lambung dengan jumlah sel-sel PMN yang lebih sedikit. Hal ini diduga karena efek antioksidan yang dimilki oleh salah satu komponen cabe rawit yaitu flavonoid. Antioksidan juga dapat menekan terjadinya inflamasi. $^{7,8}$

Namun demikian, hubungan antara tingkat keparah dari kerusakan lambung dengan dosis cabe rawit yang dikonsumsi masih belum jelas. Diduga bahwa pada dosis tertentu dari cabe rawit yang dikonsumsi (180mg pada penelitian ini), efek antiradang cabe rawit berfungsi secara maksimal. Mungkin pada dosis cabe rawit yang rendah efek antiradangnya belum cukup kuat dibandingkan dengan efek iritasinya dan sebaliknya pada penggunaan cabe rawit dosis tinggi.

\section{SIMPULAN}

Berdasarkan hasil penlitian ini dapat disimpulkan bahwa lambung tikus wistar yang diberikan cabe rawit menunjukkan tanda-tanda gastritis akut pada gambaran 
mikroskopisnya. Gambaran mikroskopis lambung tikus wistar yang diberi dosis cabe rawit sebanyak 180mg menunjukkan tandatanda gastritis akut yang lebih ringan dibandingkan dengan dosis cabe rawit yang lebih rendah.

\section{DAFTAR PUSTAKA}

1. Price SA, Wilson LM. Patofisiologi Konsep Klinis Proses-proses Penyakit. Edisi 6. Jakarta: Penerbit Buku Kedokteran EGC, 2005. h. 417-33.

2. Michael JC, Mark AS, Makoto T, Tobias AR, Jon DL, David J. The Capsaicin Receptor: A Heat-Activated Ion Channel in The Pain Pathway. 1997:389:816.

3. Geppeti P, Trevisani M. Activation and Sensitisation of the Vanilloid Receptor: Role in Gastrointestinal Inflammation and Function. British Journal of Pharmacology. 2004;141:1313-20.
4. Bortolotti M, Coccia G, Grossi G, Miglioli $\mathrm{M}$. The Treatment of Functional Dyspepsia with Red Pepper. Aliment Pharmacol Ther. 2002;16:1075-82.

5. Bortolotti M, Coccia G, Grossi G. Red Pepper and Functional Dyspepsia. New England Journal of Medicine. 2002;346:947-48.

6. Aihara E, Hayashi M, Sasaki Y, Kobata A, Takeuchi K. Mechanisms Underlying Capsaicin-Stimulated HCO3 Secretion in the Stomach Comparison with Mucosal Acidification. The Journal of Pharmacology and Experimental Therapeutics. 2005;315:423-32.

7. Tanaman Obat Indonesia, Cabe Rawit. Diakses Oktober 2012. URL: http://www.iptek.net.id/ind/pd_tanobat/view .php?mnu=2\&id=213.

8. Huang D, Ou B, Prior RL. The Chemistry behind Antioxidant Capacity Assays. Journal of Agricultural and Food Chemistry. 2005;53:1841-56. 